Василишина О. В., кандидат сільськогосподарських наук

Уманський національний університет садівництва

Постоленко Є. П., кандидат сільськогосподарських наук

Дослідна станція помології імені Л. П. Симиренка IC НАAН

\title{
ЗМІНИ БІОХІМІЧНИХ ПОКАЗНИКІВ ПЛОДІВ ВИШНІ ЗАЛЕЖНО ВІД СОРТУ ТА СПОСОБУ ЗАМОРОЖУВАННЯ
}

\begin{abstract}
Рещензент - доктор сільськогосподарських наук В. В. Любич
Мета статті - вивчення впливу особливостей сорту та способу заморожування на якісні показники плодів вишні.

Методика дослідження. Дослідження тривали протягом 2016-2018 рр. з плодами вишні сортів: Жадана, Шанс, Елегантна, Оптимістка, Подбєльська, Альфа, Пам'ять Артеменка, вирощених на дослідній станиії помології імені Л. П. Симиренка ІС НААН. Плоди вишні, зібрані у споживчій стадї стиглості, попередньо сортували, інспектували, мили, заморожували у пластикових стаканах за температури -22-24 ${ }^{\circ} \mathrm{C}$ в попередньо підготовлених иукрових сиропах за такими варіантами: розсипом (контроль); у $25 \%$ иукровому сиропі; $20 \%$ иукровому сиропі з додаванням $4 \%$ аскорутину; $45 \%$ иукровому сиропі. Зберігали за температури $-18{ }^{\circ} \mathrm{C}$.

Результати дослідження. Дослідження показали, щзо вміст иукру в свіжих плодах вишні в межах 10,14-10,96\%. Після заморожування плодів вишні в 45 \% иукровому сиропі та в 20 \% иукровому сиропі з додаванням 4\% аскорутину втрати иукрів найменші $i$ складають 2,26-8,88\% та 3,3-10,16\% відповідно. Вміст кислот у дослідних плодах вишні складає 1,67-2,02\%, найменший він для сорту Елегантна -1,67 \%, а найвищий - Пам'ять Артеменка 2,02\%. Протягом трьох місящів заморожування, порівняно із свіжими плодами, вміст кислот знизився на 2,19-11,9\%, а в кінці заморожування відбулось незначне підвищення їх вмісту на 0,5-3,47\%.

Елементи наукової новизни. У досліджснні проаналізовано зміну показників якості плодів вишні за їх низькотемпературного заморожування розсипом та в иукрових сиропах. Найбільш гармонійний смак відчувався у плодів вишні сортів Альфа, Пам'ять Артеменка та Шанс. Найменше зниження иукрово-кислотного індексу зафіксовано у плодах вишні, заморожених в 45 \% иукровому сиропі та в $20 \%$ розчині иукру з додаванням $4 \%$ аскорутину.
\end{abstract}

Практична значущість. Для збереження гармонійного смаку з високим иукрово-кислотним індексом плоди вишні необхідно заморожувати в 20 \% розчині иукру з додаванням 4 \% аскорутину.

Ключові слова: плоди вишні, сорт, заморожування, иукри, кислоти, иукрово-кислотний індекс.

Василишина Олена Володимирівна - кандидат сільськогосподарських наук, доцент кафедри технології зберігання і переробки плодів та овочів, Уманський національний університет садівництва, вул. Інститутська, 1, м. Умань, Черкаська область, 20301, Україна, e-mail: elenamila@i.ua, ORCID ID: 0000-0002-1066-4009.

Постоленко Євгеній Петрович - кандидат сільськогосподарських наук, завідувач відділу захисту рослин та аналітичних вимірювань, Дослідна станція помології ім. Л. П. Симиренка IC НАAН, вул. Симиренка, 9, с. Мліїв-1, Городищенський район, Черкаська область, 19512, Україна, e-mail: evgen780@ukr.net.

Постановка проблеми. Вишня (Prunus cerasus L.) досить поширена кісточкова культура, завдяки високій харчовій цінності та сенсорним властивостям. Хімічний склад плодів вишні залежить від сорту, умов та зони вирощування, зокрема цукри складають $6,5-21,5 \%$. Кислоти в них містяться в кількості 0,7-3,0\%, насамперед, яблучна і лимонна [6]. Ягода має інтенсивний червоний колір і кисло-солодкий смак та містить значну кількість біологічно активних компонен- тів, корисних для здоров'я людини, таких як поліфеноли та органічні кислоти. Антоціани, наявні в плодах вишні, надають їі червоного кольору, проявляють антиоксидантну, протизапальну, антибактеріальну та антидіабетичну активність. Органічні кислоти, які зумовлюють кислий смак, додатково стимулюють секрецію травних ферментів, вітамінів, мінералів і відповідають за перебіг хімічних реакцій в організмі.

Однак вишня є сезонним фруктом і більшість 
технологічних процесів викликають значну деградацію іiі біологічно активних речовин. Тому на сьогодні шукають нові рішення цієї проблеми, які б забезпечили збереження харчової та органолептичної цінності плодів вишні [12].

Щоб звести до мінімуму втрати сировини при переробці плодів використовують різні методи. Одним із них, який дозволить зберегти поживну цінність, не спричиняючи при цьому занадто великого збільшення виробничих витрат, є заморожування.

Аналіз основних досліджень і публікацій, у яких започатковано розв'язання проблеми. Заморожування - найпростіший метод, який успішно застосовується для тривалого зберігання багатьох плодів, що забезпечує подовження терміну зберігання. Сьогодні заморожені плоди становлять велику і важливу продовольчу групу. Їх заморожують різними способами, залежно від використання: цілими, половинками, в цукровому сиропі.

Для покращення харчової цінності використовують осмотичне зневоднення у водних розчинах цукру 3 різними концентраціями 3 додаванням антиоксидантів, структуроутворювачів тощо [1, 2, 7, 14]. При цьому сироп є кріопротектором. У результаті проходження осмотичних процесів у сироп із плодів відбувається вилучення клітинної води та кисню 3 тканин. У результаті висока концентрація розчинних речовин у клітині знижує температуру замерзання і зменшує замерзання всередині клітини, що запобігає структурному пошкодженню плоду [7, 11].

За літературними даними загалом використовують цукрові сиропи, як бар'єр для перенесення кисню і попередження потемніння продукту, iз концентрацією цукру 30-60 \%. Результати експериментів свідчать, що плоди, заморожені в цукрових сиропах, покращують органолептичні показники: смак, запах, колір і харчову цінність замороженої продукції $[11,13]$.

Для покращення якості продукції, крім цукру, в сиропи додають аскорбінову кислоту, аскорутин та інші. Цінність такого препарату як аскорутин полягає в тому, що у його складі $є$ аскорбінова кислота та рутин - біологічно активні речовини, які потенціюють дію один одного, внаслідок чого досягається гальмування процесів перекисного окислення, що дозволяє зберегти високу якість продукту $[9,13,15]$.

У заморожених плодах у результаті окисновідновних процесів відбуваються зміни у вмісті хімічного складу, що впливає на якість продукції. За дослідження О. В. Голуб та ін., у процесі заморожування ці зміни незначні, за виключен- ням вітаміну С [1].

Дослідженнями A. Stan та M. Е. Рора встановлено, що кислотність плодів вишні після заморожування змінюється незначно та коливається до і після заморожування в межах, \%: 1,08 $\pm 0,02$ i $1,22 \pm 0,03$. Більш значне зниження було зафіксовано за вмістом сухої речовини [14].

Загалом у заморожених плодах вишні в розчинах цукру зменшується вміст сухих розчинних речовин на 7\%, цукрів - 4 \%, кислот - $12 \%$ [9].

Метою досліджень було вивчення впливу особливостей сорту та способу заморожування на якісні показники плодів вишні.

Для досягнення поставленої мети поставлено такі завдання: проаналізувати вміст цукрів та кислот у плодах вишні різних сортів та способів заморожування; встановити залежність між вмістом цукрів та кислот плодів за цукровокислотним індексом; обгрунтувати придатність сортів та способів для заморожування плодів вишні.

Матеріали і методи досліджень. Дослідження проводили протягом 2016-2018 рр. 3 плодами вишні сортів: Жадана, Шанс, Елегантна, Оптимістка, Подбєльська, Альфа, Пам'ять Артеменка, вирощених на дослідній станції помології імені Л. П. Симиренка IC НААН.

Плоди вишні, зібрані в споживчій стадії стиглості, попередньо сортували, інспектували, мили, заморожували в попередньо підготовлених цукрових сиропах у пластикових стаканах за температури $-22-24{ }^{\circ} \mathrm{C}$, зберігали за температури $-18^{\circ} \mathrm{C}$ до 6 місяців.

Попередньо підготовлені плоди вишні заморожували за наступними варіантами:

- розсипом (контроль);

- у 25 \% цукровому сиропі;

- 20 \% цукровому сиропі 3 додаванням $4 \%$ аскорутину;

- 45 \% цукровому сиропі.

До та після заморожування, протягом трьох та шести місяців у плодах визначали вміст цукрів $[4,8]$ та титрованих кислот [5].

Дослідження відбувалися згідно 3 методичними рекомендаціями 3 проведення досліджень зі швидкозамороженими плодами, ягодами i овочами [3]. Хімічний склад заморожених плодів вишні досліджено з урахуванням втрат маси.

Математичну обробку даних проводили на персональному комп'ютері за програмою «Excel 2000» та Statistica.

Результати досліджень. Як свідчать результати досліджень (рис. 1), вміст цукру в плодах вишні змінювався протягом заморожування та залежав від сорту та способу заморожування. 


\section{СІЛЬСЬКЕ ГОСПОДАРСТВО. РОСЛИННИЦТВО}

Зокрема, у свіжих плодах вишні він коливався в межах 10,14-10,96\%. Після заморожування вміст цукрів знизився на 0,2-11,44\%. Причому втрати вмісту цукрів для плодів вишні сорту Альфа були незначні $(0,2-1,9 \%)$, тоді як для сортів Жадана та Оптимістка дещо вищі (2,1-5,88 \%). Для плодів вишні сортів Пам'ять Артеменка, Шанс, Елегантна та Подбєльська
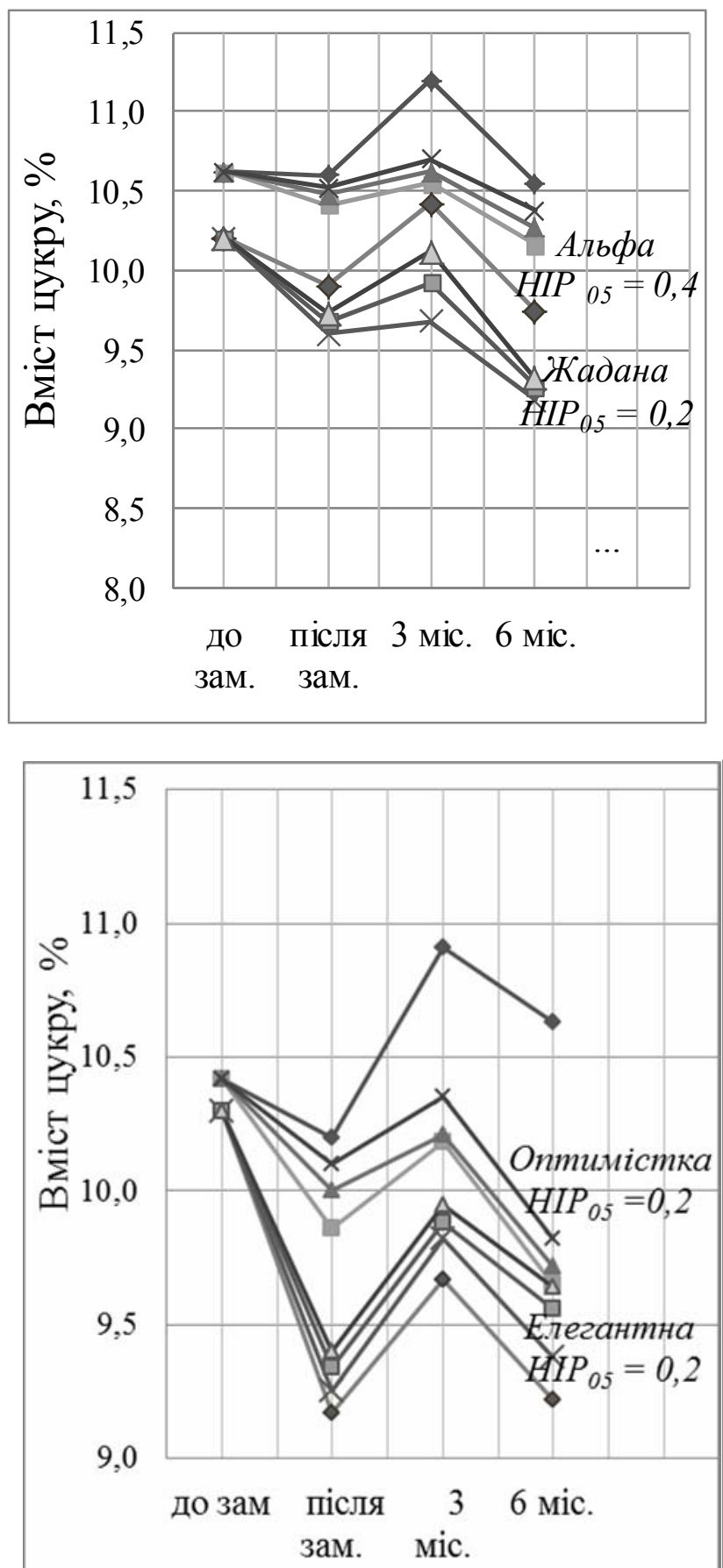

втрати цукрів були на рівні 4,84-10,97 \%.

Спосіб обробки також впливав на зміну вмісту цукрів у плодах вишні. Найменші втрати їх вмісту залежно від сорту спостерігали для плодів вишні, заморожених у $45 \%$ цукровому сиропі, порівняно зі свіжими плодами $(0,94-9,86 \%)$ та в $20 \%$ цукровому сиропі 3 додаванням $4 \%$ аскорутину $(1,32-10,26 \%)$.
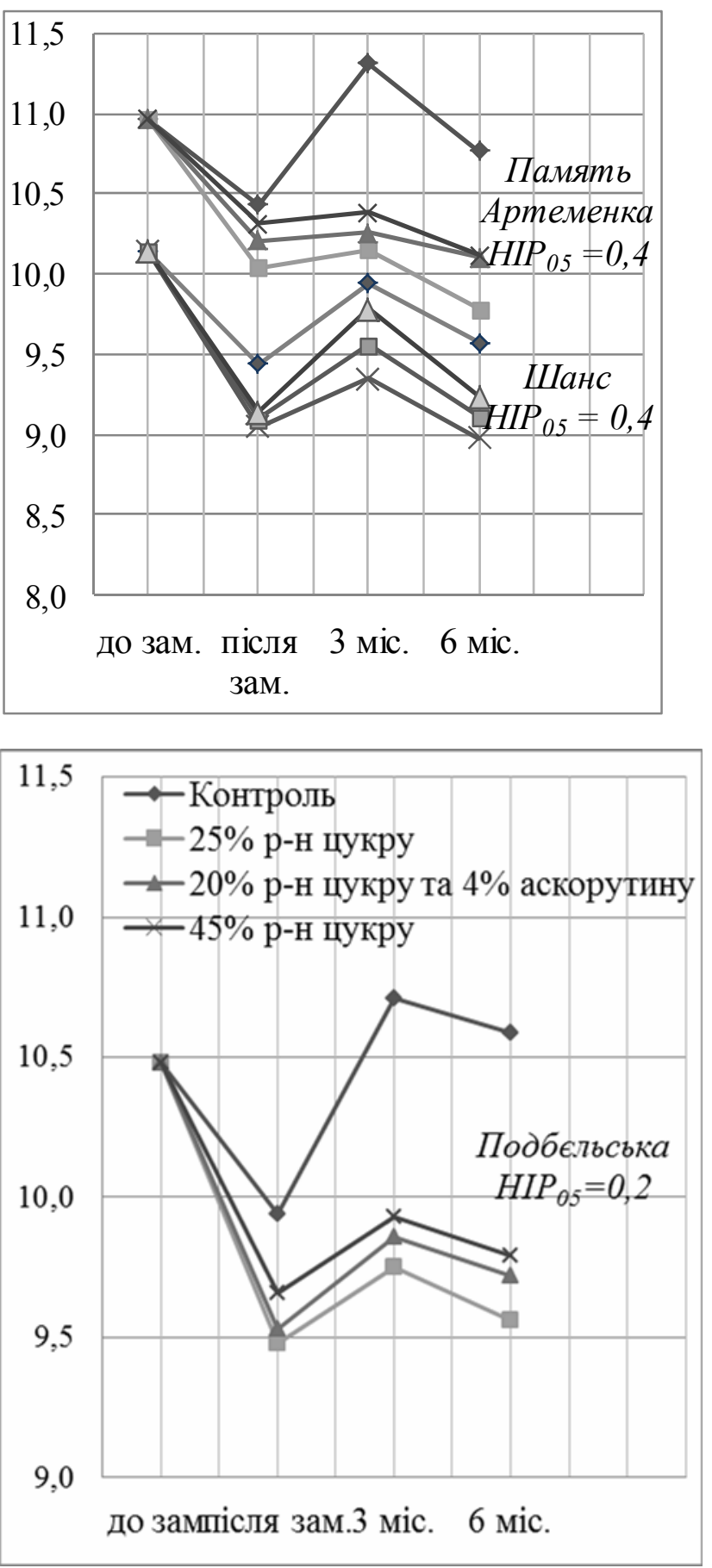

Рис. 1. Зміна вмісту цукрів у плодах вишні протягом заморожування (середнє 2016-2018 рр.) $\left(H I P_{05}=0,2\right)$

Джерело: власні дослідження. 
Після трьох місяців заморожування відбулося незначне підвищення вмісту цукрів у контрольному варіанті порівняно зі свіжими плодами на $2,15-5,46 \%$. У всіх решти варіантів відбулося подальше зниження вмісту цукрів, але їх вміст дещо перевищував показники цукрів після заморожування плодів вишні. Незначне підвищення вмісту цукру в заморожених плодах вишні з використанням цукрових сиропів пов'язано з дифузією сахарози після розморожування плодів та проходженням окисновідновних реакцій, на що вказують також результати досліджень І. Д. Сазоновой [10].

На кінець зберігання заморожених плодів вишні вміст цукру зменшився на 0,66-11,44 \% і залежав від сорту та способу обробки. Зокрема, найменші втрати вмісту цукрів на кінець зберігання у плодах вишні сортів Альфа (0,66-2,26\%), а також Оптимістка $(2-5,76 \%)$, Жадана $(4,51-8,63 \%)$. Найвищі втрати їх вмісту по сортах Елегантна (6,41-10,49\%), Шанс (5,62-11,44\%). Середніми показниками втрат вмісту цукрів відрізнялися сорти: Пам'ять Артеменка $(1,73-7,66 \%)$ та Подбєльська (6,58-8,78 \%).

Залежно від способу заморожування найменші втрати цукрів на кінець зберігання для плодів вишні, заморожених в $45 \%$ цукровому сиропі $(2,26-8,88 \%)$ та в $20 \%$ цукровому сиропі 3 додаванням $4 \%$ аскорутину (3,3-10,16\%). Що також підтверджують результати досліджень С. С. Дерябиной [2] про те, що зберігання в рідкому середовищі кісточкових плодів підвищує вміст дисахарів в 2,2 рази в рідкому середовищі та в 2,9 в повітряному середовищі. Загалом же вміст цукрів зменшується, що пов'язано 3 їх ферментативним

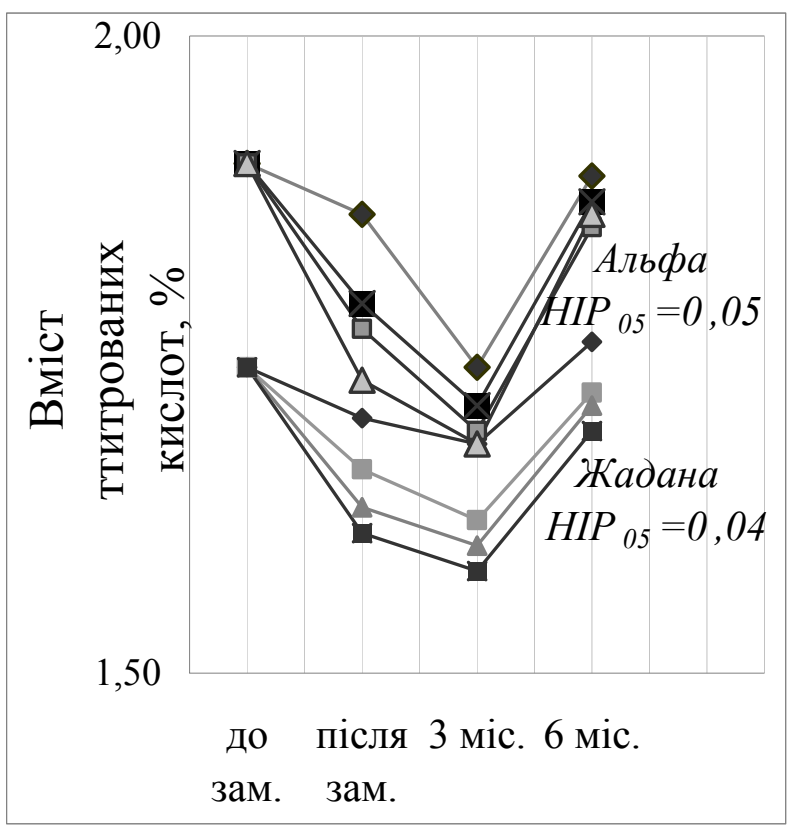

гідролізом.

Крім цукрів смак плодів вишні зумовлюють кислоти, вміст яких у плодах залежно від сорту складає $1,67-2,02 \%$ (рис. 2). Найнижчий він для сорту Елегантна $(1,67 \%)$, а найвищий для Пам'ять Артеменка (2,02\%).

Після заморожування плодів вишні, порівняно зі свіжими плодами, їх вміст зменшився на 0,55-9,84\%. Істотне зниження вмісту кислот для плодів вишні, заморожених у цукрових сиропах, що пов'язано з осмотичними процесами та дифузією цукру в плоди вишні.

Після трьох місяців заморожування відбулося подальше зниження кислот у всіх варіантах досліду на 2,19-11,9 \%. На кінець заморожування плодів вишні незначно підвищився вміст кислот на 0,5-3,47 \%, на що також указують результати досліджень А. Stan та М. Е. Рора [14].

Відношення вмісту цукрів до кислот показує цукрово-кислотний індекс, який характеризує смак продукції. На рис. 3 показано цукрово-кислотний індекс плодів вишні протягом заморожування.

У свіжих плодах вишні цукрово-кислотний індекс залежно від сорту складав 5,2-6,1. Найбільш гармонійним смаком відрізнялися плоди вишні сортів Альфа $(6,1)$, Пам'ять Артеменка $(5,9)$ та Шанс $(6,07)$ з цукрово-кислотним індексом - 6 .

Після заморожування плодів вишні цукровокислотний індекс знизився на 0,03-0,46. Необхідно зазначити, що найменше зниження цукровокислотного індексу у плодах вишні, заморожених в $45 \%$ цукровому сиропі $(5,01-6,14)$ та в $20 \%$ розчині цукру 3 додаванням $4 \%$ аскорутину $(4,9-6,01)$ порівняно із свіжими плодами.

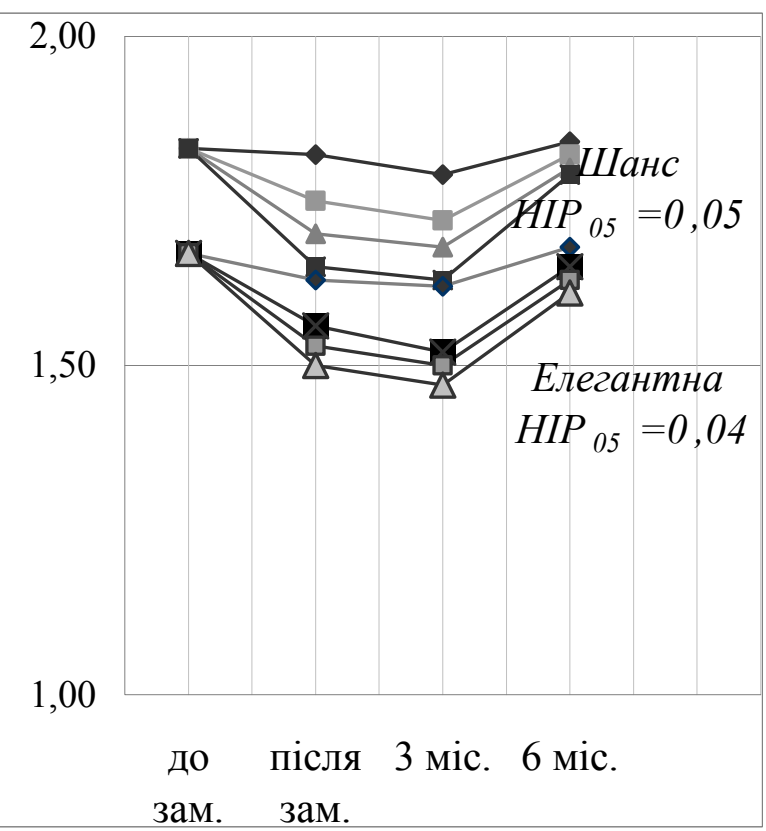




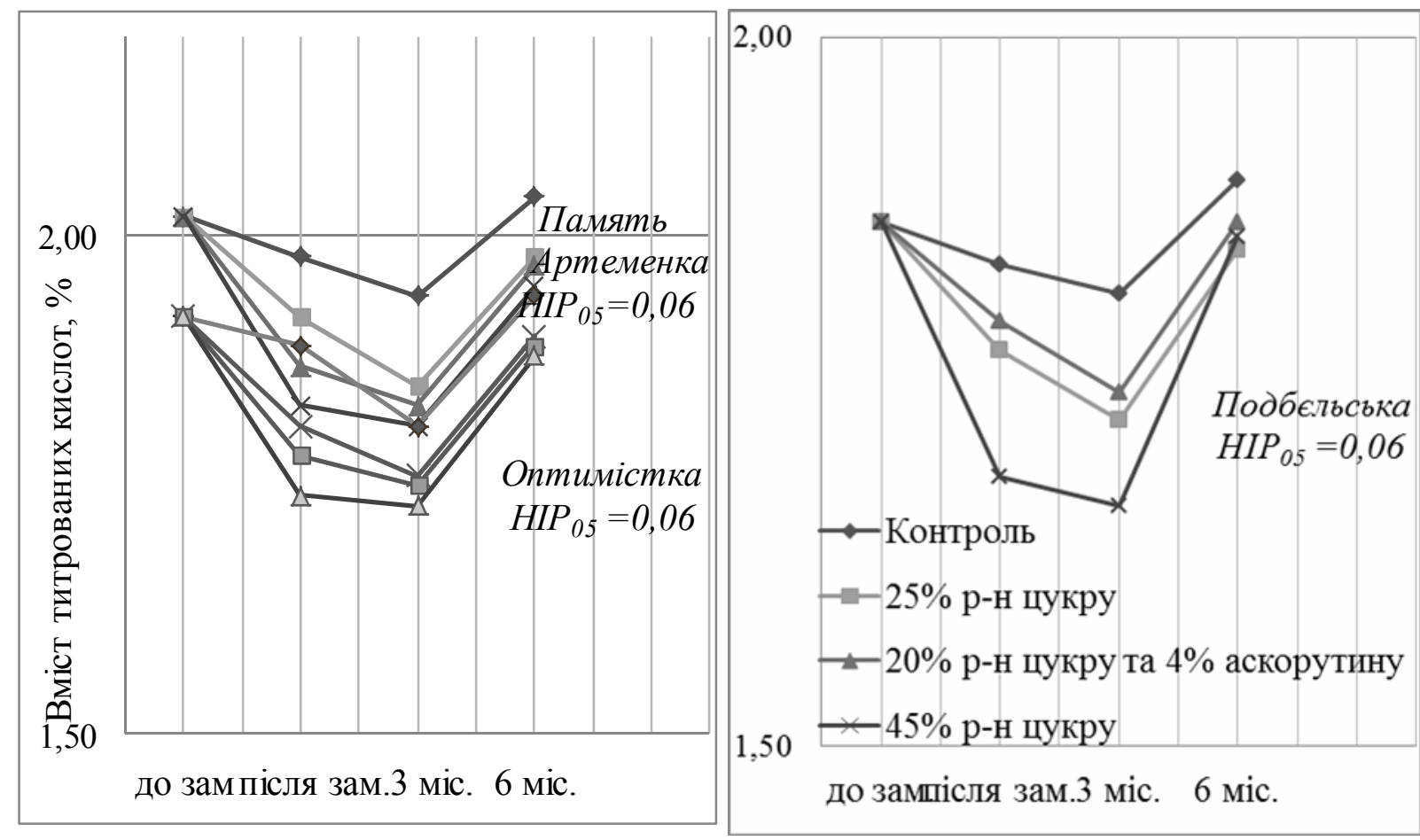

Рис. 2. Зміна вмісту титрованих кислот в плодах вишні протягом заморожування (середнс 2016-2018 рp.) $($ HIP05 = 0,05)

Джерело: власні дослідження.

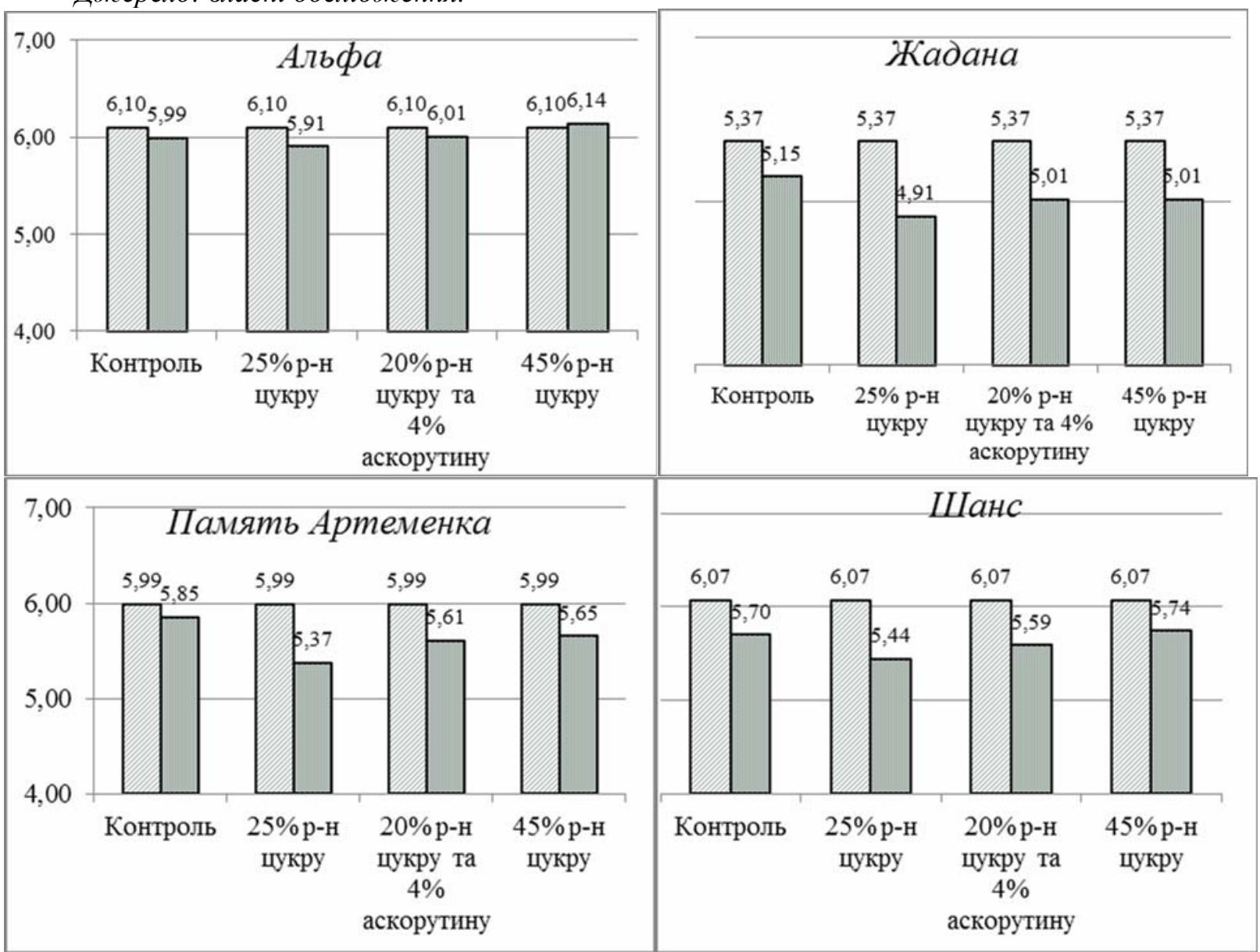


СІЛЬСЬКЕ ГОСПОДАРСТВО. РОСЛИННИЦТВО
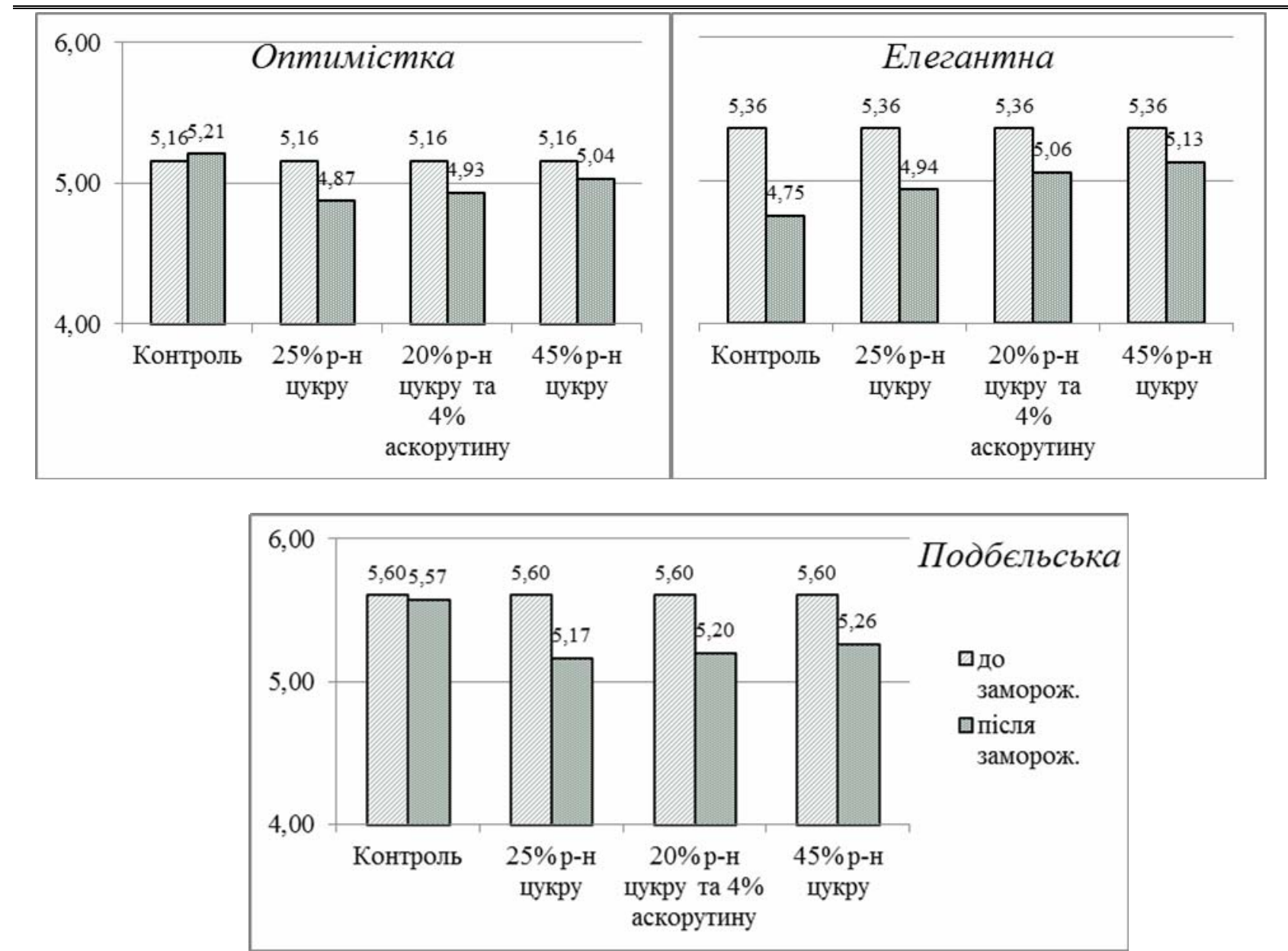

Рис. 3. Цукрово-кислотний індекс плодів вишні після заморожування $($ НІРО5= 0,2)

Джерело: власні дослідження.

Висновок. Як свідчать результати досліджень вміст цукру в свіжих плодах вишні був у межах 10,14-10,96\%. Після заморожування плодів вишні в $45 \%$ цукровому сиропі та в $20 \%$ цукровому сиропі $з$ додаванням $4 \%$ аскорутину втрати цукрів на кінець зберігання, порівняно зі свіжими плодами, найменші і складають 2,26-8,88 \% та 3,3-10,16\% відповідно.

Вміст кислот у дослідних плодах вишні складає 1,67-2,02\%, найменший він для сорту Елегантна - 1,67\%, а найвищий - Пам'ять Артеменка 2,02 \%. Протягом трьох місяців заморожування, порівняно зі свіжими плодами, вміст кислот знизився на 2,19-11,9 \%, а в кінці замо-

\section{БІБЛІОГРАФІЯ}

1. Голуб О. В., Позняковский В. М., Жарков $A$. $C$. Влияние заморозки на качественные показатели ягод вишни. Пищевая промышленность. 2009. № 7. С 32-33.

2. Дерябина С. С. Разработка технологии замораживания косточковых плодов в жидких рожування відбулося незначне підвищення їх вмісту на $0,5-3,47 \%$.

Найбільш гармонійним смаком відрізнялися плоди вишні сортів Альфа, Пам'ять Артеменка та Шанс $з$ цукрово-кислотним індексом - 6 . Найменше зниження цукрово-кислотного індексу у плодах вишні, заморожених в $45 \%$ цукровому сиропі $(5,01-6,14)$ та в $20 \%$ розчині цукру 3 додаванням $4 \%$ аскорутину $(4,9-6,01)$.

Тому для впровадження у виробництво рекомендовано сорти Альфа, Пам'ять Артеменка та Шанс заморожувати в $20 \%$ розчині цукру 3 додаванням $4 \%$ аскорутину.

хладоносителях : дис. канд. техн. наук : 05.18.04. Санкт-Петербург, 2003. 137 с.

3. Дженеева С. Л., Анисимова В. Я., Іванова C. $B$. Методические указания по проведению исследований с быстрозамороженными плодами, ягодами и овощами. Москва, 1989. 32 с. 
4. ДСТУ 4954:2008. Продукти перероблення фруктів та овочів. Методи визначання цукрів. Київ : Держспоживстандарт України, 2009. 17 с.

5. ДСТУ 4957:2008. Продукти перероблення фруктів та овочів. Методи визначання титрованої кислотності. Київ : Держспоживстандарт України, 2009. 10 с.

6. Колесникова А. Ф. Вишня и черешня. Москва : Фолио, 2003. 256 с.

7. Коробкина 3. В., Мандрыка В. І., Даниленко Г. В. О качестве плодов и ягод, замороженных в сахарном сиропе различной концентрации. Консервная и овощесушильная промьшленность. 1979. № 11. С. 13-16.

8. Найченко В. М. Практикум з технології зберігання і переробки плодів та овочів. Київ : ФАДА ЛТД, 2001. $211 \mathrm{c}$.

9. Осокіна Н. М., Василишина О. В. Якість плодів вишні за різних способів заморожування. Наукові праці Національното університету харчових технологій. 2015. № 2. С. 203-209.

10. Сазонова И.Д. Ягодные культуры как сырье для технической переработки. Научные труды Северо Кавказского федерального науч-

\section{REFERENCES}

1. Golub, O. V., Poznjakovskij, V. M., Zharkov, A. S. (2009). Vlijanie zamorozki na kachestvennye pokazateli jagod vishni [Effect of freezing on the quality indicators of cherry berries]. Pishhevaja promyshlennost', № 7, pp. 32-33 [In Russian].

2. Derjabina, S. S. (2003). Razrabotka tehnologii zamorazhivanija kostochkovyh plodov $\mathrm{v}$ zhidkih hladonositeljah [Development of technology for freezing stone fruit in liquid coolants]. Doctorals thesis. Sankt-Peterburg [In Russian].

3. Dzheneeva, Je. L., Anisimova, V. Ja., Ivanova, S. V. (1989). Metodicheskie ukazanija po provedeniju issledovanij s bystrozamorozhennymi plodami, jagodami $i$ ovoshhami [Guidelines for conducting research with quick-frozen fruits, vegetables and vegetables]. Moskva [In Russian].

4. DSTU 4954:2008. Produkti pereroblennja fruktiv ta ovochiv. Metodi viznachannja cukriv [DSTU 4954:2008. Fruit and vegetable processing products. Methods of determination of sugars]. (2008). Kyiv [In Ukrainian].

5. DSTU 4957:2008. Produkti pereroblennja fruktiv ta ovochiv. Metodi viznachannja titrovanoï kislotnosti [DSTU 4957:2008. Fruit and vegetable processing products. Methods of determination of titrated acidity]. (2008). Kyiv [In Ukrainian]. ного иентра садоводства, виноградарства, виноделия. 2018. Том 20. С. 125-134.

11. Ancos B., Sanchez-Moreno C., PascualTeresa S., Cano M. P. Fruit Freezing Principles. Handbook of Fruits and Fruit Processing. Blackwell Publishing, 2006. $688 \mathrm{p}$.

12. Nowicka P., Wojdylo A., Lech K., Figiel A. Influence of osmodehydration pretreatment and combined drying method on the bioactive potential of sour cherry fruits. Food and Bioprocess Technology. 2015. Vol. 8 (4). P. 824-836

13. Poiana M. A., Diana M., Alexa E. Influence of home-scale freezing and storage on antioxidant properties and color quality of different garden fruits. Bulgarian Journal of Agricultural Science. 2010. Vol. 16 (2). P. 163-171.

14. Stan A., Popa M. E. Pretreatment and freezing storage effect on antioxidant capacity of sour cherries and correlation with color changes. Romanian Biotechnological Letters. 2015. Vol. 20 (5). P. 10726-10834.

15. Vasylyshyna $E$. Inflaence of freezing and storing cherry fruit on its nutritional value. Acta scientiarum polonorum technologia alimentaria. 2016. Vol. 15 (2). P. 145-150.

6. Kolesnikova, A. F. (2003). Vishnja i chereshnja [Sour cherry and sweet cherry]. Moskva: Folio [In Russian].

7. Korobkina, Z. V., Mandrika, V. I., Danilenko, G. V. (1979). O kachestve plodov i jagod, zamorozhennyh v saharnom sirope razlichnoj koncentracii [On the quality of fruits and ice frozen in sugar syrup of various concentrations]. Konservnaja $i$ ovoshhesushil'naja promyshlennost, 11, pp. 13-16 [In Russian].

8. Najchenko, V. M. (2001). Praktikum $z$ tehnologii zberigannja $i$ pererobki plodiv ta ovochiv [Workshop on the preservation and processing of fruits and vegetables]. Kyiv: FADA LTD [In Ukrainian].

9. Osokina, N. M., Vasilishina, O. V. (2015). Jakist' plodiv vishni za riznih sposobiv zamorozhuvannja [The quality of the fruits is cherry in different ways of freezing]. Naukovi praci Nacional'nogo universitetu harchovih tehnologij, 2, pp. 203-209 [In Ukrainian].

10. Sazonova, I. D. (2018). Jagodnye kul'tury kak syr'e dlja tehnicheskoj pererabotki [Berry crops as a raw material for technical processing]. Nauchnye trudy Severo Kavkazskogo federal'nogo nauchnogo centra sadovodstva, vinogradarstva, vinodelija, 20, pp. 125-134 [In Russian].

11. Ancos, B., Sanchez-Moreno, C., Pascual- 


\section{СІЛЬСЬКЕ ГОСПОДАРСТВО. РОСЛИННИЦТВО}

Teresa, S., Cano, M. P. (2006). Fruit Freezing Principles. Handbook of Fruits and Fruit Processing. Blackwell Publishing [In English].

12. Nowicka, P., Wojdylo, A., Lech, K., Figiel, A. (2015). Influence of osmodehydration pretreatment and combined drying method on the bioactive potential of sour cherry fruits. Food and Bioprocess Technology, 8 (4), pp. 824-836 [In English].

13. Poiana, M. A., Diana, M., Alexa, E. (2010). Influence of home-scale freezing and storage on antioxidant properties and color quality of different garden fruits. Bulgarian Journal of Agricultural
Science, 16 (2), pp. 163-171 [In English].

14. Stan, A., Popa, M. E. (2015). Pretreatment and freezing storage effect on antioxidant capacity of sour cherries and correlation with color changes. Romanian Biotechnological Letters, 20 (5), pp. 10726-10834 [In English].

15. Vasylyshyna, E. (2016). Inflaence of freezing and storing cherry fruit on its nutritional value. Acta scientiarum polonorum technologia alimentaria, 15 (2), pp. 145-150 [In English].

Василишина Е. В., Постоленко Е. П. Изменения биохимических показателей плодов вишни в зависимости от сорта и способа замораживания

Цель статьи - изучение влияния особенностей сорта и способа замораживания на качественные показатели плодов вишни.

Методика исследования. Исследования проводились в течение 2016-2018 г2. с плодами вишни сортов: Жадана, Шанс, Элегантная, Оптимистка, Подбельская, Альфа, Память Артеменко, выращенных на исследовательской станции помологии имени Л. П. Симиренко ИС НААН. Плоды вишни собирали в потребительской стадии зрелости предварительно сортировали, инспектировали, мыли, замораживали в пластиковых стаканах при температуре $-22-24{ }^{\circ}$ С в предварительно подготовленных сахарных сиропах по следующим вариантам: россыпью (контроль); в 25 \% сахарном сиропе; $20 \%$ сахарном сиропе с добавлением $4 \%$ аскорутина; $45 \%$ сахарном сиропе. Хранили при темпераmype $-18^{\circ} \mathrm{C}$.

Результаты исследования. Исследования показали, что содержание сахара в свежих плодах вишни было в пределах 10,14-10,96\%. После замораживания плодов вишни в 45 \% сахарном сиропе и в $20 \%$ сахарном сиропе с добавлением $4 \%$ аскорутина потери сахаров небольшие и составляют 2,26-8,88\% и 3,3-10,16\% соответственно. Содержание кислот в исследуемых плодах вишни составляют 1,67-2,02\%, наименьшие они для сорта Элегантная -1,67\%, а наивысшие - Память Артеменко 2,02\%. В течение трех месяцев замораживания, по сравнению со свежими плодами, содержание кислот снизилось на 2,19-11,9\%, а в конце замораживания отмечено незначительное повымение их содержания на 0,5-3,47\%.

Элементы научной новизны. В исследовании проанализировано изменение показателей качества плодов вишни при их низкотемпературном замораживании россыпью и в сахарньх сиропах. Наиболее выраженным вкусом отличались плодь вични сортов Альфа, Память Артеменко и Шанс. Наименьшее снижение сахарно-кислотного индекса отмечено в плодах виини, замороженных в $45 \%$ сахарном сиропе и в $20 \%$ растворе сахара с добавлением $4 \%$ аскорутина.

Практическая значимость. Для сохранения выраженного вкуса с высоким сахарно-кислотным индексом плоды вишни необходимо замораживать в $20 \%$ растворе сахара с добавлением $4 \%$ аскорутина.

Ключевые слова: плоды вишни, сорт, замораживание, сахара, кислоты, сахарно-кислотный индекс.

Василишина Елена Владимировна - кандидат сельскохозяйственных наук, доцент кафедры технологии хранения и переработки плодов и овощей, Уманский национальный университет садоводства, ул. Институтская, 1, г. Умань, Черкасская область, 20301, Украина, e-mail: elenamila@i.ua, ORCID ID: 0000-0002-1066-4009.

Постоленко Евгений Петрович - кандидат сельскохозяйственных наук, заведующий отделом защиты растений и аналитических измерений, Опытная станция помологии им. Л. П. Симиренко ИС НААН Украины, ул. Симиренко, 9, с. Млиев-1, Городищенский район, Черкасская область, 19512, Украина, e-mail: evgen780@ukr.net. 
Vasylyshyna O. V., Postolenko Ye. P. Changes in the biochemical parameters of cherry berries depending on the variety and method of freezing

The purpose of the article is to study the influence of variety peculiarities and the method of freezing on quality indices of cherry berries.

Research methods. The research was carried out during 2016-2018 with berries of cherry varieties: Zhadana, Shans, Elehantna, Optymistka, Podbielska, Alfa, Pamiat Artemenka, grown at the Research Station of Pomology named after L. P. Symyrenka of the IH NAAS. Fruits of berries were picked at the consumer stage of maturation, then they were presorted, inspected, washed, frozen in plastic cups at the temperature of $-22-24{ }^{\circ} \mathrm{C}$ in prepared sugar syrups according to the following variants: in bulk (control); in $25 \%$ sugar syrup; in $20 \%$ sugar syrup with $4 \%$ of ascorutin added; in $45 \%$ sugar syrup. The berries were stored at $-18^{\circ} \mathrm{C}$.

The research results. Studies have shown that the content of sugar in fresh cherry berries was within the range of 10.14-10.96\%. After freezing of cherry berries in 45\% sugar syrup and $20 \%$ sugar syrup with adding $4 \%$ of ascorutin the loss of sugar was the least $-2.26-8.88 \%$ and $3.3-10.16 \%$, correspondingly. The acid content in the studied cherry berries was 1.67-2.02\%, it was the smallest in Elehantna variety $1.67 \%$, and the highest in Pamiat Artemenka-2.02\%. During the three months of freezing, the acid content decreased by 2.19-11.9\% as compared with fresh berries, and at the end of freezing there was a slight increase in their content by $0.5-3.47 \%$.

The elements of scientific novelty. The berries of Alfa, Pamiat Artemenka, and Shans varieties were distinguished by the most harmonious taste. The least decrease in the sugar-acid index in cherry was observed in berries frozen in $45 \%$ sugar syrup and $20 \%$ sugar syrup with $4 \%$ ascorutin added.

Practical significance. In order to preserve a harmonious taste with a high sugar-acid index, the cherry berries must be frozen in $20 \%$ solution of sugar with adding $4 \%$ of ascorutin.

Key words: cherry berries, variety, freezing, sugars, acids, sugar-acid index.

Vasylyshyna Olena Volodymyrivna - Candidate $(\mathrm{PhD})$ of Agricultural Sciences, Associate Professor, Department of Technology of Storage and Processing of Fruits and Vegetables, Uman National University of Horticulture, 1, Institutska st., Uman, Cherkasy region, 20301, Ukraine, e-mail: elenamila@i.ua, ORCID ID: 0000-0002-1066-4009

Postolenko Yevheniy Petrovych - Candidate $(\mathrm{PhD})$ of Agricultural Sciences, Head of the Department of Plant Protection and Analytical Measurements, Research Station of Pomology named after L. P. Symyrenka of the IS NAAS 9, Symyrenka st., v. Mliiv-1, Gorodyshchy district, Cherkasy region, 19512, Ukraine, e-mail: evgen780@ukr.net.

Стаття надійшла до редакції 25.02.2019 р.

Бібліографічний опис для цитування :

Василишина О. В., Постоленко С. П. Зміни біохімічних показників плодів вишні залежно від сорту та способу заморожування. Вісник ПДАА. 2019. № 1. С. 18-26.

DOI 10.31210/visnyk2019.01.02

(C) Василишина Олена Володимирівна, Постоленко Свгеній Петрович, 2019 